\title{
Recent developments on the extreme right scene in Germany and the concept of waves of political extremism ${ }^{1}$
}

\author{
AGATA KAŁABUNOWSKA \\ MASTER OF SCIENCE, 4TH YEAR PHD STUDENT IN POLITICAL SCIENCE,
}

\author{
Institute of Political Science and International Relations, Jagiellonian University \\ MSc, 4th year PhD student in political science \\ e-mail: a.kalabunowska(at)gmail.com
}

Keywords Germany, extreme right, far right, periodization

Abstract The academic literature generally recognizes three waves of popularity for the extreme right in postwar Germany. The most common periodization was devised by Ekkart Zimmermann and Thomas Saafeld and recognized by the vast majority of academics working in the English language. Nevertheless, there are several other possibilities for structuring the history of the German far right, by dividing it into four or more phases. The biggest shortcoming of the various periodizations is the fact that they do not cover the period of the migration crisis - a time of huge importance for Germany as a country and the German political scene in particular. This article aims at filling this gap. The author considers the plausibility of the hypothesis that over recent years, there has been a new wave of right-wing political extremism and provides substantial evidence for its existence.

Najnowsze zmiany na scenie skrajnej prawicy w Niemczech a koncepcja fal ekstremizmu politycznego

Słowa kluczowe Niemcy, ekstremizm prawicowy, skrajna prawica, periodyzacja

Abstrakt W literaturze dotyczącej ekstremizmu prawicowego w powojennych Niemczech wskazuje się zazwyczaj trzy fale popularności skrajnej prawicy. Najbardziej znany sposób periodyzacji zaproponowany został przez Ekkarta Zimmermanna i Thomasa Saafelda, a następnie przejęty przez znaczną część badaczy w obszarze anglojęzycznym. Niemniej jednak istnieją także inne możliwości podziału historii niemieckiej skrajnej prawicy - na cztery bądź więcej faz. Największym mankamentem dostępnych periodyzacji jest to, że nie obejmują one okresu kryzysu migracyjnego, mającego kluczowe znaczenie dla Niemiec, a zwłaszcza dla niemieckiej sceny politycznej. Niniejszy artykuł usiłuje wypełnić tę lukę. Autorka rozważa w nim prawdopodobieństwo hipotezy zakładającej, że w ostatnich latach mamy do czynienia z nową falą ekstremizmu prawicowego, a także przedstawia na jej poparcie liczne dowody.

\footnotetext{
1 This paper has been published as part of a research project number 2018/28/T/HS5/00335, financed by the National Science Centre in Poland.
} 


\section{Introduction}

The phenomenon of political extremism is nothing new and neither is the extreme right, which is considered one of its variations (Backes, 2006); contemporary research on postwar rightwing radicalism abounds in theoretical and methodological approaches. Far-right extremism has intensified significantly in recent years, with the organizations and parties positioned on the far right fringes of the political scene currently enjoying what is perceived as their heyday. The concept of extreme right became an object of heated public debate, especially during the so-called migration crisis, which serves as the historical background to this analysis.

There is, however, a field of research, located at the border between historical considerations and political science, that does not attract so much academic attention - the periodization of the history of extremism. Reflections concerning current developments on the radical scene will surely become more organized and substantive, providing that previously-researched extremist patterns from the past are taken into consideration.

This article examines this neglected issue, using contemporary Germany as an example. The research questions guiding this paper were the following: What are the possible ways to periodize the history of the extreme right in Germany? Which socio-political categories were relevant for the proposed periodizations? And finally: Is it plausible to announce the existence of a new period of popularity at the present moment in time?

The paper aims to confirm the hypothesis, which assumes that current developments on the far right scene in Germany should be classified as a completely new wave for the popularity of the extreme right. After clarifying the terminological aspects of the research subject, this paper uses a comparative perspective to look at the ways of periodization that are currently available. Finally, based on an analysis of current social and political conditions in Germany, along with the condition of the far right itself, the paper suggests further development for the concept of waves of right-wing extremism.

Please note that all the translations from German and Polish are the author's, unless indicated otherwise.

\section{Terminology}

Growing intensification in the use of terms such as "extremism" or "radicalism" does not necessarily go along with a growing clarity of these terms. Quite the contrary - there is a lack of precision in these terms. As Jürgen Winkler rightly pointed out

The multitude of research subjects, theoretical terms and hypotheses - frequently vague and barely correlated - leaves a lot of space for diverse interpretations. (...) The lack of one commonly accepted and precise language of research represents one of the biggest weaknesses of the studies on right-wing extremism (Winkler, 2001).

Therefore the first part of the article will be dedicated to clarifying the meaning of the term "extreme right". 
In the German legal and constitutional system, more important than the potential extremism of an individual, organization or a party is the determination as to whether they are in line with the constitutional democratic order or not. Therefore, in legal terminology, terms such as "verfassungswidrig" (unconstitutional, and therefore illegal) and "verfassungsfeindlich" (anticonstitutional) or "verfassungskritisch" (critical of the constitutional democratic order) prevail over the names of the various forms of particular extremisms.

On the other hand the Federal Office for the Protection of the Constitution (Bundesamt für Verfassungsschutz, BfV), responsible for monitoring individuals and groupings suspected of being "verfassungswidrig", tends to use slightly different terminology in its publications. Although the Federal Office may potentially help with the banning of various extreme groupings, an important task for it is also to furnish public opinion and the government with appropriate information. In annual reports, the Federal Office therefore uses specific names for the various antidemocratic powers, e.g. right-wing extremism, left-wing extremism or terrorism. Right-wing extremism is understood in this case to be a specific political outlook, which assumes that belonging to an ethnic group, a nation or a race is decisive in the assessment of someone's value as a person (Bundesamt für Verfassungsschutz, 2018, p. 44).

Definitions do not become clearer when we look at the literature in political science. German political scientists may be divided into those who follow the premises of the theory of political extremism ("Extremismustheorie") and those who suggest alternative solutions. The theory of political extremism was proposed by Uwe Backes and Eckhart Jesse, and further developed by, inter alia, Armin Pfahl-Traughber. An aim of this theory, in contrast to studies on totalitarian regimes, was to examine the phenomenon of "extremeness" within a democratic political order. It understands political extremism as a collective term for all those political phenomena (both beliefs and actions), whose common denominator is the negation of the fundamental rules of the democratic order (Backes \& Jesse, 1989, p. 33). Among other variations of extremism, left-wing and right-wing extremisms can be differentiated on the basis of their attitude towards one particular value of the democratic order - the equality of people. Left-wing extremists are hostile towards the democratic state due to their willingness to remove the socio-political order in general and free the people from the restrictions of an unequal system. On the other hand, rightwing extremists are antidemocratic due to their willingness to sustain the inequality of people, based on their origins, nationality, ethnic or racial background, which makes this political stream incompatible with the rules of the constitutional democratic order (Backes \& Jesse, 1989, p. 43).

This approach has, on the one hand, been heavily criticized in German academia, but on the other hand - due to its strictly German relevance - neglected in political science elsewhere. A widely-known argument against the "Extremismustheorie" is the fact that it puts the barely-correlated various forms of antidemocratic movements under one broad term of political extremism, without precise differentiation. Another important shortcoming of the theory is that it focuses on the contrast between what is democratic and what is not, leaving much space for individual interpretations (in terms of, for example what it actually means to be democratic and who decides what is democratic). Additionally, it tends to divide political behaviors into "good" and "evil", despite the fact that the political center, perceived here as "good", is not always free from radicalisms either. Finally, this definition is hard to operationalize, nor does it explain the origins of the phenomena that it describes (see: Jaschke, 2006; Stöss, 2015). 
As a result, various political scientists have been trying to come up with an alternative, consensual definition of what the extreme right is, by depriving the term of both constitutional and theoretical connotations. None of the alternatives seems to be widely acceptable. For the purposes of the article I have decided to use that suggested by Hans-Georg Jaschke, which claims that right-wing extremism should be understood as the entirety of attitudes, behaviors and actions, organized or not, that come from a general conviction of the racially- or ethnically-driven social inequality of people, which demand the ethical homogeneity of nations and reject the imperative of the equality of people as stated in human rights declarations. They highlight the importance of the collective above the individual, and are therefore anti-individualistic. Additionally, they reject pluralism, including the pluralism of democratic values (Jaschke, 2001, p. 30).

An advantage of this definition is that it is positive - it focuses more on what extreme right actually is, rather than describing what extreme right is not. It is also elaborative and highlights the most important ideological element of the far right - its strong focus on the homogenous collective. Most importantly, in the contemporary confusion of terms, this definition enables us to distinguish the extreme right from neighboring terms, such as populism. The more popular populist groupings are, the more problematic this distinction becomes (see: Rydgren, 2017). Finally, the definition proposed by Jaschke is broad enough to include various forms of the far right, e.g., those that currently do not fall under the legal definition, such as Alternative for Germany (Alternative für Deutschland, AfD) - a widely discussed "special case" in German political science (see: Pfahl-Traughber, 2018).

In light of these definitional considerations, it is worth highlighting that the interchangeable usage of terms such as "far right", "radical right" and "extreme right" throughout the article is dictated only by reasons of style.

\section{History of the extreme right in Germany - current approaches to periodization}

Although nearly all the monographs dedicated to the far right in Germany include a brief overview of the history of its development, not all of the researchers have made the additional effort to group the historical plots in line with any specific patterns. The most widely known depiction of the history of the German extreme right seems to be that proposed by Ekkart Zimmermann and Thomas Saafeld (Zimmermann \& Saalfeld, 1993). This gained publicity not only because it was published in English, but also thanks to Piero Ignazi, one of the most popular researchers in the field, who used it in his widely-cited monograph Extreme Right Parties in Western Europe (Ignazi, 2006, p. 63-74).

Zimmermann and Saafeld divided the postwar history of the far right in Germany into three phases: the first took place in the late 1940s and early 1950s, the second in the mid- to late- 1960s and the third at the turn of the 1990s. The first phase was characterized by the birth of the political scene following the Second World War, as well as the difficult economic reconstruction. The far right was not overly successful - the scene was fragmented and repressed by political opponents. The second wave of right-wing extremism is closely connected to the electoral successes of the National Democratic Party of Germany (Nationaldemokratische Partei Deutschlands, NPD) and its later failure in the elections of 1969. This period showed the far right's high mobilizing potential across 
the whole of Germany (more precisely, West Germany at that time). The third wave, suggested by these authors, is a phase of popularity for the party Die Republikaner, public debate on the asylum law and the difficulties for the governing social democrats in leading this debate.

A huge advantage of this periodization is that the authors looked not only at the popularity of particular parties but also at the wider political environment. In their considerations they took into account the electoral successes of the far right parties, their membership and the index of politically motivated crimes, inspired or justified by right-wing ideology. They also considered the links between the successes or failures of the far right and other political powers. On the other hand, a serious shortcoming of this periodization is the lack of inclusion of so-called latent extremism, i.e., extremist potential in society in general, which could be measured by social approbation for the elements of an extreme worldview.

Another drawback is obviously the fact that due to its publication date, around 30 years of recent German history were not taken into account. Interestingly, political science was not so eager to fill this gap. Quite the contrary: the third wave of right-wing extremism has even been "prolonged" and considered to take longer than just the turn of the 1990s, as suggested by the above-mentioned model. For example, in 2009, Frank Decker and Lazaros Miliopoulos wrote about the third wave that "this wave, starting in the mid 1980s and continuing unabated to the present, has led to a number of electoral triumphs for right-wing parties" (Decker \& Miliopoulos, 2009, p. 96).

Zimmermann and Saafeld's differentiation of the three waves of right-wing extremism in Germany is not the only periodization available. Samuel Salzborn divides the various ways of dealing with the history of the far right in Germany into three types: historical-genetic, historical-programmatic and historical-contextualizing (Salzborn, 2015, p. 34). An interesting periodization, which Salzborn classifies as the historical-programmatic type, is that suggested by Richard Stöss (2010). It focuses not simply on the popularity of far right organizations in a given period of time, but rather on the prevailing political subject (called the campaign), which influences the political debate and is used by radicals to gain popularity. Stöss differentiated five phases. The first period, 1945-1961, was dominated by two campaigns: one calling for the reestablishment of the Third Reich, and another called the revisionist campaign. In the second period, 1962-1982, both these campaigns were present; however, they were also accompanied by another, called the foreign flood or foreign domination campaign ("die Überfremdungskampagne"). In the third phase, 1983-1990, the far right dropped the Third Reich rhetoric. At the same time they stuck to the revisionist campaign and maintained focus on the foreign flood. In the fourth phase, 1991-2000, both topics were accompanied by a new campaign, called anti-globalist. And finally the fifth phase, which started in 2000 and according to the author lasted up to the point of publication, was dominated by three topics. These were again the foreign flood campaign and the anti-globalist campaign but also a new, anti-Islam campaign. Although this concept is remarkably convincing in terms of methodology, it again does not cover the last couple of years, which have been dominated by the migration crisis.

The furthest-reaching periodization was proposed by Gideon Botsch (Botsch, 2016). This author took a similar route to Zimmermann and Saafeld by differentiating three main phases of right-wing extremism in the following periods: 1949-1969, 1970-1989 and 1990-2009. As we can see, these phases encompass longer periods of time. Important for our considerations 
is, however, the fact that Botsch also indicated the possibility for the existence of a completely new wave after 2010. The author did not differentiate it clearly in his model but instead stated that there are several aspects in the modern political scene "speaking in favor of its existence" (Botsch, 2016, p. 67). As an example, the author gave the popularity of a new form of political protest and civil disobedience, e.g., the PEGIDA movement. He also stated that the period after 2010 was dominated by the European crisis, which had an enormous influence on the internal politics of European countries.

I believe that in the current historical moment, enriched by our observance of the migration crisis and its consequences for Germany, we are able to finalize and strengthen Botsch's proposal.

\section{Recent developments on the extreme right scene in Germany and the concept of waves of political extremism}

Several aspects of Germany's recent history point in favor of the hypothesis that there has been a new wave of right-wing popularity there in recent years.

1. First of all, the radical right scene has experienced significant structural changes since the discovery of crimes committed by the National Socialist Underground (Nationalsozialistischer Untergrund, NSU) in 2011. The NSU was an extreme right terrorist organization operating undetected for more than a decade. Those members of the grouping who were still living following detection were accused of multiple bombing attacks, robberies and murders on foreign-born German citizens (Schellenberg, 2013). The trial, considered to be the longest and most expensive in Germany's postwar history (Förster \& Funke, 2018, p. 5), took place between 2013 and 2018. Evidence gathered during the trial enabled the initiation of a new delegalization process for another far right grouping - the NPD. As a side note it is worth mentioning, that this was already the second attempt to ban this party (see: Backes, 2019; Flemming, 2003). It ended with the Federal Constitutional Court's conclusion that, although the ideology and activities of the party were not compatible with the democratic order, it could still legally operate, due to its limited significance on the political scene. The NSU and NPD cases encouraged members of the radical scene to look for new solutions. It became clear that the constitutional and legal system would closely examine and strictly punish any similar activities in the future.

2. As a result, the German far right started to look for new strategic and rhetorical opportunities. One of the results of this reorientation was the establishment of the parties Die Rechte and Der III. Weg as well as the German branch of the Identitarian Movement (Identitäre Bewegung Deutschland, IBD) in 2012, followed by the establishment of the AfD in 2013. All of these, as well as many other smaller groupings, represent various operational forms of right-wing radicalism. While the scene became fragmented, many different forms of political activism intensified. At the same time the new far right organizations tried to dispense with their most radical slogans, turning their strategy into something that could be called political mimicry (see: Speit, 2018). The typical Nazi and neo-Nazi organizations, so popular in the $90 \mathrm{~s}$, have been pushed to the margins, while the allegedly more moderate forms of the extreme right have come to the fore. 
3. Another consequence of these reorientations was inspired by the development of the migration crisis and the growing numbers of foreigners living in the country. Due to the limited scope of this paper it is just worth noting that $36 \%$ of all asylum applications in Europe in 2015 were submitted in Germany. A year after this number had increased to $59 \%$ (Bundesamt für Migration und Flüchtlinge, 2018, p. 30). The number of new asylum seekers combined with an already significant number of immigrants resulted in the fact that every eighth person living in Germany was born outside the country (Bundesamt für Migration und Flüchtlinge, 2018, p. 112). An aftermath of these developments was a change in the policy focus of the German far right. Anti-Islam and identitarian discourse become dominant among the newly-established organizations. Additionally, even the "old" representatives of the scene, such as the NPD and Pro Bewegung, started to shift their sympathizers' attention towards these new, heavily-debated issues. Similar anti-immigrant and xenophobic discourse became popular within German society, which was revealed, for example, by the enormous popularity of the PEGIDA movement. It is worth adding that these demographic changes were also accompanied by the growth of politically-motivated crimes. The number grew from around 32,000 crimes in the years 2013 and 2014 to $39,000-41,500$ at the peak of the migration crisis. The vast majority were driven by right-wing - hence hostility-driven - ideology (Bundesministeriums des Innern, für Bau und Heimat, 2019, p. 3).

4. The development of the migration crisis along with the re-grouping processes on the far right scene were accompanied inter alia by the diminishing popularity of the "traditional parties" in the period between the Bundestag elections of 2013 and 2017. This became evident with Angela Merkel's difficulties in forming her fourth cabinet at the turn of 2018. The German social democrats also experienced their worst-ever electoral results. The lack of trust in the biggest mainstream parties might have been the result of a general dissatisfaction with political parties ("Parteiverdrossenheit") or with politics generally ("Politikverdrossenheit"). The growing number of German citizens not taking part in the elections is one of the expressions of this process. A report from the Friedrich Ebert Foundation found that the percentage of non-voters increased from around $12 \%$ in the early 1980 s to almost $28 \%$ in the Bundestag elections of 2009. In regional elections there was a growth in non-participation from around $23 \%$ to more than $43 \%$ (Güllner, Molthagen, 2013). This is not to say that the change in the approach towards politics results directly from the popularity of the extreme right, but that the far right operates within this constantly-changing political landscape.

5. All of the above changes were accompanied by a significant shift in German public discourse, where radical opinions formerly believed to have been "reserved for the political margins" (Magierowski, 2013) become socially acceptable. The scale of public interest in radical opinions becomes clear when, for example, examining the popularity of Thilo Sarazzin's publications (e.g., Deutschland schafft sich ab: Wie wir unser Land aufs Spiel setzen or Feindliche Übernahme: Wie der Islam den Fortschritt behindert und die Gesellschaft bedroht), which quickly became bestsellers despite containing statements considered xenophobic, anti-Islam and racist. The extent of Sarazzin's accusations led the UN Committee on the Elimination of Racial Discrimination to closely examine his 
books (UN takes Germany..., 2013). Although he should not be considered a representative of any extreme right organization, the scale of the public discussion inspired by his books represents the spirit of the socio-political debate in the period of time under discussion.

Consideration of the developments on the far right scene in such a wide political and historical context enables the hypothesis to be confirmed. In recent years, the German radical scene has strengthened not only in terms of the numbers of new groupings and their membership; it has also gained additional space in the public discourse, benefiting from the general atmosphere in the public debate. The year 2012, the starting point for the reorganization of the far right scene, should be considered as the start date for the new wave, while the AfD's success in the Bundestag elections of 2017 can be considered its peak. We are able to determine this new wave of right-wing radicalism both in the light of changes within the far right scene but also due to their correlation with other socio-political developments in the country that took place during the migration crisis.

\section{Conclusions}

The discussion on the development of right-wing extremism in this article clearly demonstrates that extreme organizations and their successes should not be analyzed in historical isolation. It is difficult to perceive extremism as a stand-alone element of history. These organizations are closely-linked and interdependent. Additionally, in the particular case of Germany, "the history of extreme right (...) is on its own an important element of the history of the democratization of the country" (Botsch, 2016, p. 44). Therefore, increased awareness of the nuances of the far right scene, and reasons for its popularity and unpopularity over different periods of time, can contribute not only to a better understanding of extremism but also of the history of the country itself.

Even more importantly, careful observation of the reasons for the establishment and further development of radical tendencies can help with discovering patterns - the conditions in which they blossom and perish. Further detailed interpretation can help both with sensitization of public opinion to the problem and with designing possible preventive measures.

\section{References}

Backes, U. (2006). Politische Extreme: eine Wort- und Begriffsgeschichte von der Antike bis in die Gegenwart. Göttingen: Vandenhoeck \& Ruprecht.

Backes, U. (2019). Banning political parties in a democratic constitutional state: the second NPD ban proceedings in a comparative perspective. Patterns of Prejudice, 2 (53), 136-151. DOI: https://doi.org/10.1080/003132 2X.2019.1572275

Backes, U., Jesse, E. (1989). Politischer Extremismus in der Bundesrepublik Deutschland. Vol. 2: Analyse. Cologne: Verlag Wissenschaft und Politik.

Botsch, G. (2016). „Nationale Opposition” in der demokratischen Gesellschaft. In: F. Virchow, M. Langebach, A. Häusler (eds.), Handbuch Rechtsextremismus (p. 43-82). Wiesbaden: Springer VS.

Bundesamt für Migration und Flüchtlinge (2018). Das Bundesamt in Zahlen 2017. Asyl, Migration und Integration. Nürnberg: Bundesamt für Migration und Flüchtlinge. Retrieved from: https://www.bamf.de/SharedDocs/Anlagen/DE/Publikationen/Broschueren/bundesamt-in-zahlen-2017.html (4.05.2019). 
Bundesamt für Verfassungsschutz (2018). Verfassungsschutzbericht 2017. Berlin: Bundesministerium des Innern, für Bau und Heimat. Retrieved from: https://www.verfassungsschutz.de/de/oeffentlichkeitsarbeit/publikationen/ verfassungsschutzberichte/vsbericht-2017 (4.05.2019).

Bundesministeriums des Innern, für Bau und Heimat (2019). Politisch Motivierte Kriminalität im Jahr 2018 Bundesweite Fallzahlen. Retrieved from: https://www.bmi.bund.de/SharedDocs/downloads/DE/veroeffentlichungen/2019/pmk-2018.pdf?__blob=publicationFile\&v=2 (9.07.2019).

Decker, F., Miliopoulos, L. (2009). From a Five to a Six-Party System? Prospects of the Right-wing Extremist NPD. German Politics and Society, 2 (27), 92-107. DOI: https://doi.org/10.3167/gps.2009.270207.

Flemming, L. (2003). Das gescheiterte NPD-Verbotsverfahren - Wie aus dem „Aufstand der Anständigen” der „Aufwand der Unfähigen” wurde. Jahrbuch Extremismus \& Demokratie, 15, 159-176.

Förster, A., Funke, H. (2018). Der Nationalsozialistische Untergrund, das Ringen um Aufklärung und die Folgen für die demokratische und politische Kultur in Thüringen. Retrieved from: http://library.fes.de/pdf-files/bueros/ erfurt/14822.pdf (4.05.2019).

Güllner, M., Molthagen, D. (2013). Nichtwähler in Deutschland: eine Studie im Auftrag der Friedrich-Ebert-Stiftung. Berlin: Friedrich-Ebert-Stiftung, Forum Berlin. Retrieved from: https://library.fes.de/pdf-files/dialog/10076.pdf (4.05.2019).

Ignazi, P. (2006). Extreme right parties in Western Europe. Oxford: Oxford University Press.

Jaschke, H.-G. (2001). Rechtsextremismus und Fremdenfeindlichkeit: Begriffe, Positionen, Praxisfelder. Wiesbaden: Westdeutscher Verlag.

Jaschke, H.-G. (2006). Politischer Extremismus. Wiesbaden: VS Verlag für Sozialwissenschaften.

Magierowski, M. (2013). Zmęczona: rzecz o kryzysie Europy Zachodniej. Kraków: Ośrodek Myśli Politycznej.

Pfahl-Traughber, A. (2018). Ist die „Alternative für Deutschland“ eine rechtsextremistische Partei? Eine Erörterung aus politikwissenschaftlicher Sicht. Jahrbuch für Extremismus- und Terrorismusforschung 2017/18 (I), 208-239.

Rydgren, J. (2017). Radical right-wing parties in Europe: What's populism got to do with it? Journal of Language and Politics, 4 (16), 485-496. DOI: https://doi.org/10.1075/jlp.17024.ryd.

Salzborn, S. (2015). Rechtsextremismus: Erscheinungsformen und Erklärungsansätze. Baden-Baden: Nomos.

Schellenberg, B. (2013). Right-Wing Extremism and Terrorism in Germany: Developments and Enabling Structures. In: R. Melzer, S. Serafin (eds.), Right-wing extremism in Europe: country analyses, counter-strategies and labor-market oriented exit strategies (p. 35-73). Retrieved from: https://library.fes.de/pdf-files/dialog/10031.pdf (4.05.2019).

Speit, A. (2018). Das Netzwerk der Identitären: Ideologie und Aktionen der Neuen Rechten. Berlin: Ch. Links Verlag.

Stöss, R. (2010). Rechtsextremismus im Wandel. Berlin: Friedrich-Ebert-Stiftung, Forum Berlin.

Stöss, R. (2015). Kritische Anmerkungen zur Verwendung des Extremismuskonzepts in den Sozialwissenschaften. Downloaded from: https://www.bpb.de/politik/extremismus/rechtsextremismus/200099/kritische-anmerkungen-zur-verwendung-des-extremismuskonzepts-in-den-sozialwissenschaften (4.05.2019).

UN takes Germany to task for 'racist' Sarrazin. (2013). The Local. Retrieved from: https://www.thelocal. de/20130419/49241 (4.05.2019).

Winkler, J. R. (2001). Rechtsextremismus. Gegenstand - Erklärungsansätze - Grundprobleme. In: W. Schubarth, R. Stöss (eds.), Rechtsextremismus in der Bundesrepublik Deutschland. Eine Bilanz (p. 38-68). Opladen: Leske + Budrich.

Zimmermann, E., Saalfeld, T. (1993). The three waves of west German Right-Wing Extremism, In: P.H. Merk1, L. Weinberg (eds.), Encounters With The Contemporary Radical Right, The three waves of West German right-wing extremism (p. 50-74). Boulder: Westview Press. 